\title{
The first records of coenagrionid damselflies (Odonata: Zygoptera: Coenagrionidae: Neoerythromma sp. and Nehalennia sp.) from Mexican Amber (Miocene)
}

\author{
Andrew J. Ross ${ }^{1, *}$, Marco Antonio Coutiño José2 ${ }^{2}$ André $\mathrm{Nel}^{3}$ \\ ${ }^{1}$ National Museum of Scotland, Chambers Street, Edinburgh, EH1 1JF, Scotland, UK. \\ ${ }^{2}$ Dirección de Paleontología - Secretaria de Medio Ambiente e Historia Natural, Calzada de Los Hombres Ilustres S/N Antiguo Parque \\ Madero, Colonia Centro C.P. 29000, Mexico. \\ ${ }^{3}$ Institut de Systématique, Évolution, Biodiversité, ISYEB - UMR 7205 - CNRS, MNHN, UPMC, EPHE, Muséum national \\ d'Histoire naturelle, Sorbonne Universités, 57 rue Cuvier, CP 50, Entomologie, F-75005, Paris, France. \\ *a.ross@nms.ac.uk
}

\begin{abstract}
Two specimens of the damselfly (Odonata: Zygoptera) family Coenagrionidae are described from Mexican amber of early Miocene age, identified as Neoerythromma sp. and Nehalennia sp. They constitute the first records of the family Coenagrionidae from this amber, and the first fossil records of the genera Neoerythromma and Nehalennia.
\end{abstract}

Keywords: Amber, Odonata, Neoerythromma, Nehalennia, Miocene, Mexico.

Resumen

Dos ejemplares de caballito del diablo (Odonata: Zygoptera) familia Coenagrionidae se describen desde el ámbar mexicano de edad Mioceno temprano, identificado como Neoerythromma sp. y Nehalennia sp. Ellos constituyen los primeros registros de la familia Coenagrionidae de este ámbar, y los primeros registros fósiles de los géneros Neoerythromma y Nehalennia.

Palabras clave: Ámbar, Odonata, Neoerythromma, Nehalennia, Mioceno, México.

\section{Introduction}

Mexican amber is one of the major types of fossiliferous ambers in the world and has yielded about 200 families of arthropods so far. Most of the amber has been extracted from Simojovel in Chiapas State. The resin was produced by the legume tree Hymenaea mexicana which grew in a forest close to a mangrove swamp (Solórzano Kraemer, 2010). The amber is considered to be about $15-20$ million years old which mostly corresponds to the Burdigalian stage of the Miocene (International Chronostratigraphic Chart v2014/02 $<$ http://www.stratigraphy.org $>$ ).
Dragonflies and damselflies (Odonata) are well known from the fossil record with hundreds of described species. However they are comparatively rare in amber even if more than 75 specimens are recorded (Bechly and Wichard, 2008), mainly from Baltic amber. Their rarity is not surprising given that they are large and have no attraction to resin, though may use tree branches as somewhere to rest. For them to get trapped in sticky resin is purely by accident.

The order Odonata was not recorded as occurring in Mexican amber by Solórzano Kraemer (2007, 2010), however two specimens of Zygoptera are now known and described below. The most complete specimen was figured 
in an exhibition guidebook by Ross and Sheridan (2013).

\section{Material and Methods}

The specimens are preserved in pieces of relatively clear, yellow amber. The amber pieces were ground and polished before being examined and photographed. Fossils were examined and measured using a Meiji RZ-Techno stereomicroscope. Photographs were taken using a Wild Makroscope M420 with Nikon D700 camera.

We follow the wing venation nomenclature of Riek and Kukalová-Peck (1984), amended by Nel et al. (1993) and Bechly (1996). The higher classification of fossil and extant Odonatoptera, as well as familial and generic characters followed in the present work are based on the phylogenetic system proposed by Bechly $(1996,2016)$ at least for the definitions of the damselfly families. Abbreviations for wing venation are as follow: $\mathrm{AA}=$ analis anterior; $\mathrm{CuA}=$ cubitus anterior; $\mathrm{CuP}=$ cubitus posterior; $\mathrm{d}=$ discoidal cell; IR 1 and IR2 = intercalary radial veins; lestine oblique vein = an oblique vein between IR2 and RP2 close to the base of RP2; $\mathrm{MA}=$ media anterior; $\mathrm{MP}=$ media posterior; $\mathrm{N}=$ nodus, pseudo-transverse veins are aligned crossveins in distal part of wing; $\mathrm{Pt}=$ pterostigma; $\mathrm{RA}=$ radius anterior; $\mathrm{RP}=$ radius posterior; $\mathrm{Sn}=$ subnodus; $\mathrm{ScP}=$ subcosta posterior; $\mathrm{Ax} 1$ and $\mathrm{Ax} 2$ antenodal cross-veins.

\section{Systematic Palaeontology}

Order: Odonata Fabricius, 1793

Family: Coenagrionidae Kirby, 1890

Genus Neoerythromma Kennedy, 1920

Type species: Neoerythromma cultellatum (Hagen, in Selys-Longchamps, 1876)

\section{Neoerythromma sp.}

'Damselfly (Odonata: Zygoptera)' Ross and Sheridan, 2013 , p. 55 , fig. 5.

Material. Specimen NMS G.2008.34.1.1 (Figs 1-4) adult in a piece of Mexican amber, nearly complete though missing more than half of the left forewing and tip of right forewing. The head, thorax and abdomen are cracked and shrunken. The abdomen is bent in three places. Right forewing and right hindwing folded over. Housed in the National Museums Collections Centre, National Museums Scotland, Edinburgh, purchased from Roland Torikian.

Type locality. Simojovel, Chiapas State, Mexico.

Type age. Burdigalian (Miocene).

Description. Holotype, adult. Length, outstretched, from tip of head to tip of abdomen $25 \mathrm{~mm}$.

Head broad, $3 \mathrm{~mm}$ wide, with large compound eyes.

Thorax $4.5 \mathrm{~mm}$ long; venter of thorax between base of metacoxae and abdomen without a mound-like prominence.

Abdomen $19.5 \mathrm{~mm}$ long, slender; coloration not preserved; genitalia poorly preserved.

Forewing length $12.5 \mathrm{~mm}$, width $3.0 \mathrm{~mm}$; hindwing length $14.0 \mathrm{~mm}$, width $3.0 \mathrm{~mm}$. Venations of forewing and hindwing identical. Wings hyaline, petiole $2.0 \mathrm{~mm}$ long, forewing petiole $0.7 \mathrm{~mm}$ wide, hindwing petiole $0.8 \mathrm{~mm}$ wide, considerably longer than half distance from wing base to cubito-anal cross-vein, but petiole ending before level of $\mathrm{CuP}$ so that distance between end of petiole and $\mathrm{CuP}$ longer than $\mathrm{CuP}$; distance between wing base and nodus $6.2 \mathrm{~mm}$ (hindwing only, not possible to measure forewing), between nodus and pterostigma $6.6 \mathrm{~mm}$ (both wings), between pterostigma and wing apex $1.5 \mathrm{~mm}$ (hindwing only); pterostigma $0.8 \mathrm{~mm}$ long, $0.3 \mathrm{~mm}$ wide (hindwing only), with basal and distal sides moderately oblique, covering exactly one cell, only two primary antenodal crossveins, Ax2 aligned with arculus; eight postnodal crossveins well aligned with corresponding postsubnodals; no intercalary veins except normal IR2 and IR1; RP1 distinctly kinked at the insertion of pterostigmal brace vein; lestine oblique vein absent; presence of pseudo-transverse veins in distal part of wing, caused by an alignment of postnodal rows of crossveins between costal margin and hind margin; distal discoidal vein $M A b$ very oblique and long, so that anterior side of discoidal cell much shorter than posterior side, discoidal cell very acute; postsubnodal area widened in its basal part; basal part of postdiscoidal area widened; base of IR1 one cell basal of pterostigma; base of RP2 between fourth and fifth postnodal veins; MA and $\mathrm{CuA}$ zigzagged in their distal third; $\mathrm{CuA}$ ending well distal of nodus level.

Legs spiny, all with three tarsal segments and claws that distinctly bifurcate at the tip; tibial spurs barely longer than intervening spaces; prothoracic femora without black stripe.

Remark. In the piece of amber the following syninclusions also occur: gall midge (Diptera: Cecidomyiidae), parasitic wasp (Hymenoptera: Parasitica) and a wing and partial body of an ant (Hymenoptera: Formicidae). The piece also contains the head and thorax of a stingless bee (Hymenoptera: Apidae: Meliponini) and the wing and abdomen tips of a bark-louse (Psocoptera).

\section{Genus Nehalennia Selys-Longchamps, in Selys- Longchamps and Hagen, 1850}

Type species: Nehalennia speciosa (Charpentier, 1840)

\section{Nehalennia sp.}

Material. Specimen IHNFG-4896 (Figs 5-6) incomplete adult in Mexican amber, consisting of head, thorax, forewing bases and 6 legs, with tips missing from left foreleg and both hindlegs. Housed in the Colección Paleontológica de la Secretaría del Medio Ambiente e Historia Natural del Estado de Chiapas.

Type locality. Simojovel, Chiapas State, Mexico.

Type age. Burdigalian (Miocene). 
The first records of coenagionid damselflies from Mexican Amber (Miocene)

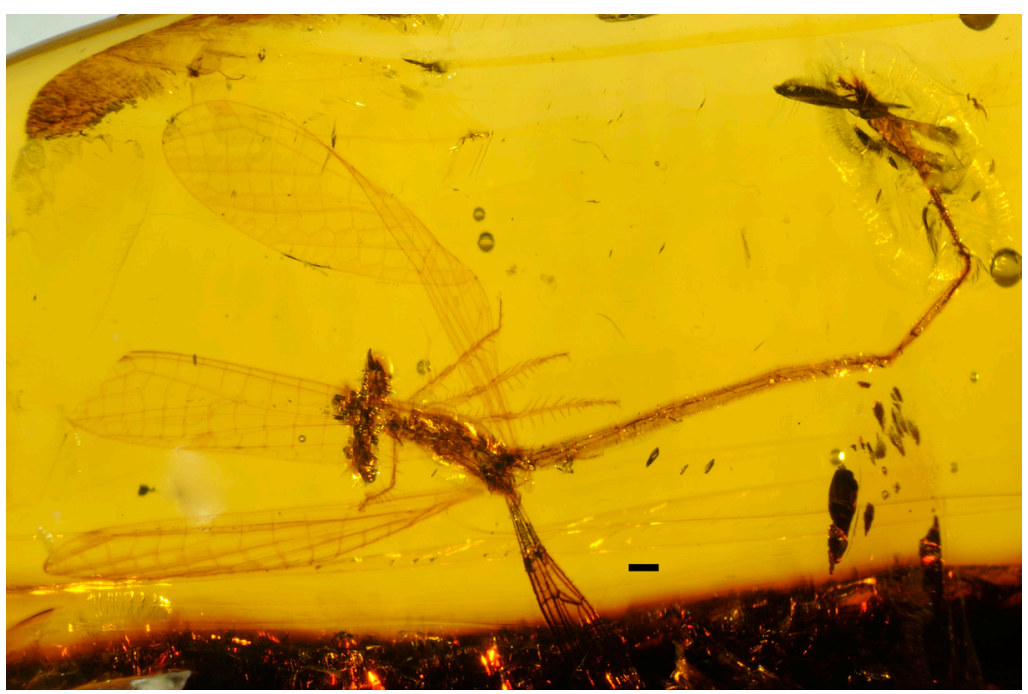

Figure 1. Neoerythromma sp., dorsal view. NMS G.2014.34.1.1.

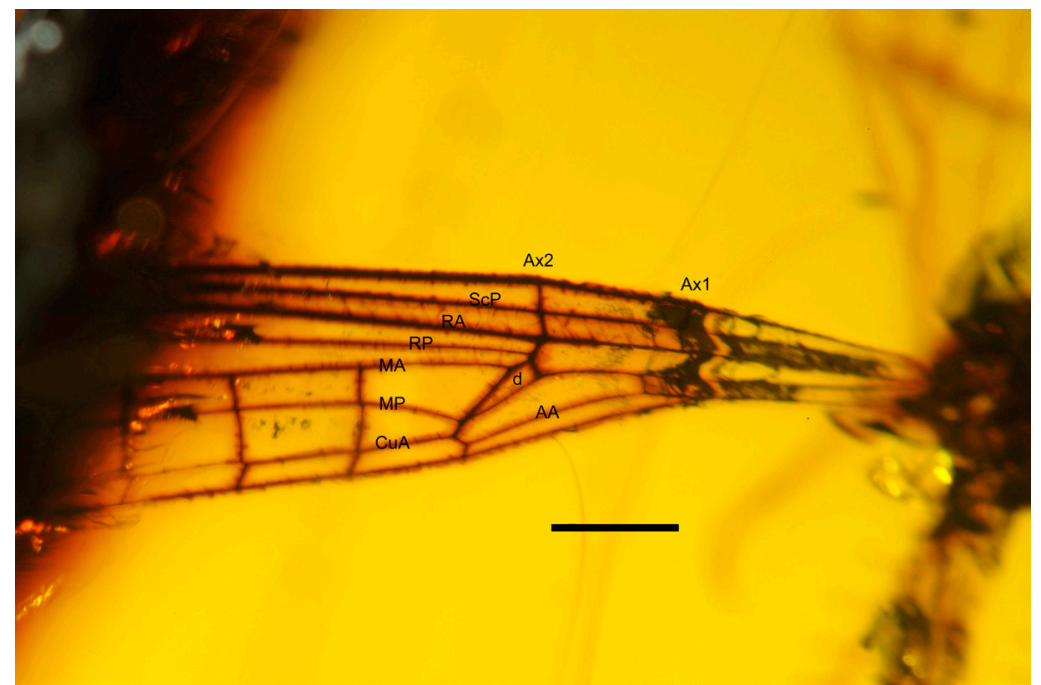

Figure 2. Neoerythromma sp., left forewing base. NMS G.2008.34.1.1. For vein abbreviations see main text.

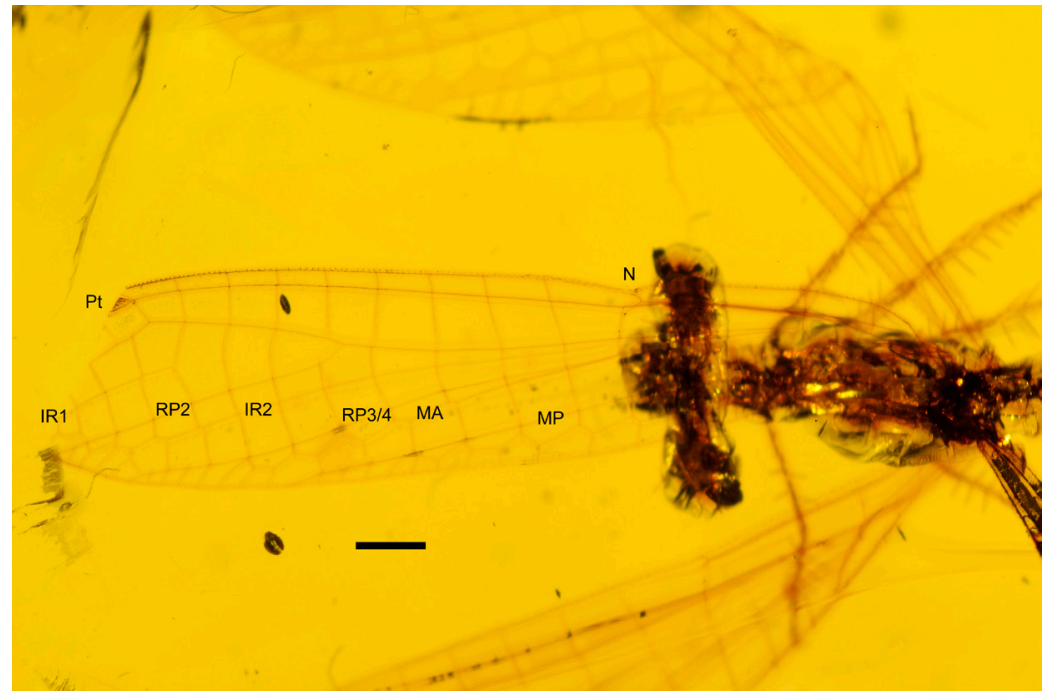

Figure 3. Neoerythromma sp., right forewing, twisted over at base. NMS G.2008.34.1.1. For vein abbreviations see main text. 


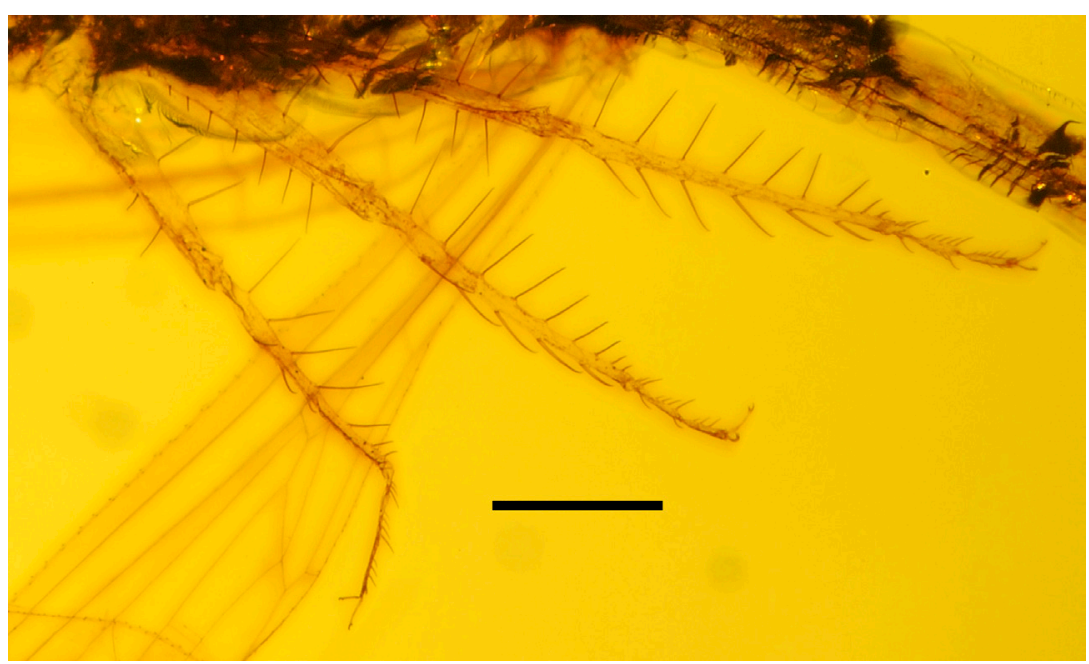

Figure 4. Neoerythromma sp., right legs, ventral view. NMS G.2008.34.1.1.

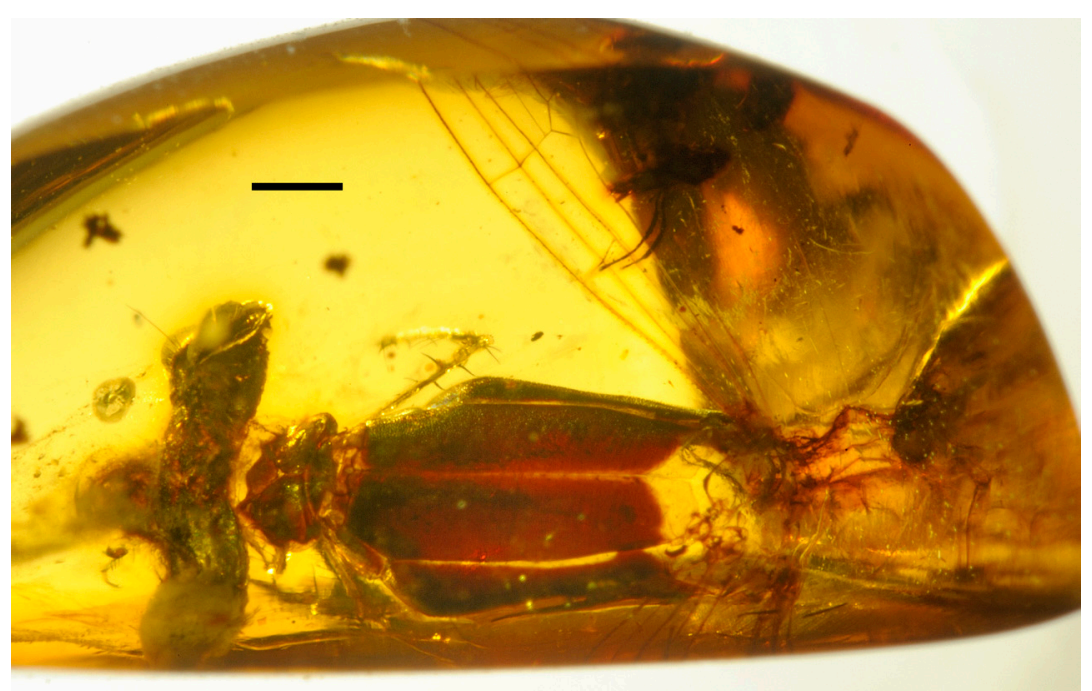

Figure 5. Nehalennia sp., dorsal view. IHNFG-4896.

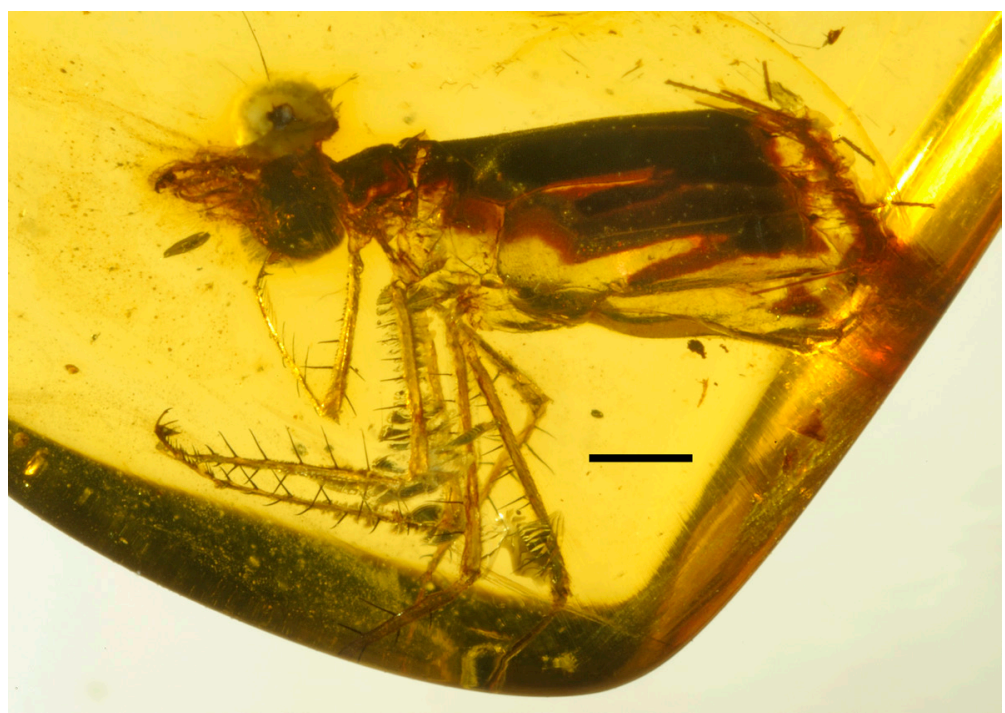

Figure 6. Nehalennia sp., lateral view. IHNFG-4896. 
Description. Head $3.5 \mathrm{~mm}$ wide, with antennae, jaws and angulate frons clearly visible.

Prothorax $1 \mathrm{~mm}$ long, rest of thorax $4 \mathrm{~mm}$ long, width $2.5 \mathrm{~mm}$; venter of thorax between base of metacoxae and abdomen without a mound-like prominence; presence of a long dark zone on the epimeron 3; dorsal dark stripes of the thorax rather extended; pale stripe between the dark dorsal and lateral stripes very narrow. Abdomen not preserved. Only wing bases preserved.

Remark. The piece of amber also contains the head and thorax of a stingless bee (Hymenoptera: Apidae: Meliponini) and the wing and abdomen tips of a bark-louse (Psocoptera).

\section{Discussion}

NMS G.2008.34.1.1 belongs to the Coenagrionidae because of the following characters: pterostigma shortened covering only one cell; RP1 distinctly kinked at the insertion of the pterostigmal brace vein; postnodal and postsubnodal crossveins aligned; lestine oblique vein secondarily absent; all intercalary veins (except IR1 and IR2) suppressed; presence of pseudo-transverse veins in the distal part of the wing, caused by an alignment of the postnodal rows of crossveins between the costal margin and the hind margin; distal discoidal vein $\mathrm{MAb}$ is very oblique, so that the anterior side of the discoidal cell is much shorter than the posterior side. The forewing venation looks like the Central American genus Neoerythromma Kennedy, 1920 in the widened postsubnodal area, widened basal postdiscoidal area, very acute discoidal cell with very long distal side MAb, and origin of IR1 (Westfall and May, 1996: fig. 189). Thus we tentatively attribute it to this genus even if the lack of information on its genitalia structures prevent identification with certainty (Kennedy, 1920).

IHNFG-4896 can also be attributed to the Coenagrionidae for the shape of the body, what is visible of its venation, and its pattern of thorax coloration. The frons of specimen IHNFG-4896 angulate in profile with a transverse ridge at junction of antefrons and postfrons plus the presence of well-developed supplementary tooth on tarsal claw suggests affinities with a group of 12 New World genera related to Telebasis, keyed in Garrison (2009). Unfortunately the first couplet of this key 'presence versus absence of a tubercle on sternum of S1' cannot be seen because this segment is missing. The thorax with a pattern of stripes the last of which run parallel to thoracic sutures, plus probably the angle of frons with a distinct carina supports a possible attribution the genus Nehalennia. This genus comprises six species, N. speciosa from Europe, plus five from the New World (Westfall and May, 1996). Specimen IHNFG-4896 differs from Nehalennia integricollis, $N$. irene, $N$. speciosa, and $N$. gracilis in the pattern of coloration of the sides of the thorax (presence of a long dark zone on the epimeron 3); from $N$. minuta in the more extended dorsal dark bands of the thorax; and from N. pallidula by the narrower pale band between the dark dorsal and lateral bands (De Marmels, 1984). But as this author indicated that the thorax coloration is rather variable in this genus, and given the fragmentary nature of the specimen it is not possible to accurately discriminate it from recent species.

Nehalennia is a New World genus with its type species $N$. speciosa currently considered as a relic species in Europe. De Marmels (1984) supposed that the most inclusive taxa are the South and Central American N. minuta and N. pallidula, and that the genus diversified in North America and reached Europe relatively recently, during or after the Oligocene. Possibly the genus was widespread in Eurasia during the Paleogene and became extinct nearly everywhere in this area, except Western Europe, during the global cooling and the Holocene glaciations, while it was maintained in Florida and Central America. It is not surprising to have it present in the Miocene of Mexico. Neoerythromma is a Central American genus still present in Mexico.

\section{Acknowledgements}

Many thanks to Bill Crighton (NMS volunteer) for taking the photographs and to Vicen Carrio and Alba Sánchez García for the Spanish abstract.

\section{References}

Bechly, G., 1996, Morphologische Untersuchungen am Flügelgeäder der rezenten Libellen und deren Stammgruppenvertreter (Insecta; Pterygota; Odonata), unter besonderer Berücksichtigung der Phylogenetischen Systematik und des Grundplanes der Odonata. Petalura, Böblingen, Special Volume 2, 402 p.

Bechly, G., 2016, Phylogenetic systematics of Odonata, available at $<$ https://dl.dropboxusercontent.com/u/13756162/Website/odonata/ system.htm>.

Bechly, G., Wichard, W., 2008, Damselfly and dragonfly nymphs in Eocene Baltic amber (Insecta: Odonata), with aspects of their palaeobiology: Palaeodiversty, 1, 37-74.

Charpentier, T., 1840, Libellulinae europaeae descriptae ac depictae. L. Voss, Lipsiae, $180 \mathrm{p}$.

De Marmels, J., 1984, The genus Nehalennia Selys, its species and their phylogenetic relationships: Odonatologica, 13 (4), 501-527.

Fabricius, J.C., 1793, Entomologia systematica emendata et aucta. Secundum classes, ordines, genera, species adjectis synonimis, locis, observationibus, descriptionibus. Tome 2. Christ. Gottl. Proft, Hafniae. 519 p.

Garrison, R.W., 2009, A synopsis of the genus Telebasis Selys (Odonata: Coenagrionidae): International Journal of Odonatology, 12, 1-121.

Kennedy, C.H., 1920, Forty-two hitherto unrecognized genera of Zygoptera: Ohio Journal of Science, 21, 83-88.

Kirby, W.F., 1890, A synonymic catalogue of Neuroptera Odonata, or dragonflies, With an appendix of fossil species: Gumey \& Jackson, London. 202 p.

Nel, A., Martinez-Delclos, X., Paicheler, J.-C., Henrotay, M., 1993, Les 'Anisozygoptera' fossiles. Phylogénie et classification (Odonata): Martinia Numéro Hors Série 3, 1-311.

Riek, E.F., Kukalová-Peck, J., 1984. Anew interpretation of dragonfly wing venation based upon Early Carboniferous fossils from Argentina (Insecta: Odonatoidea) and basic characters states in pterygote wings: Canadian Journal of Zoology, 62, 1150-1166. 
Ross, A., Sheridan, A., 2013, Amazing Amber: NMS Enterprises LimitedPublishing, Edinburgh, 64p.

Selys-Longchamps, E., 1876, Synopsis des Agrionines, 5ème légion: Agrion: Bulletin de l'Académie Royale des Sciences, des Lettres et des Beaux-Arts de Belgique 2, 41 (2-3), 1-282.

Selys-Longchamps, E., de, Hagen, H.A., 1850, Revue des Odonates ou libellules d'Europe: Mémoires de la Société Scientifique, Liège, 6: $406 \mathrm{p}$.

Solórzano Kraemer, M.M., 2007, Systematic, palaeoecology, and palaeobiogeography of the insect fauna from Mexican amber: Palaeontographica (A), 282, 1-133.
Solórzano Kraemer, M.M., 2010, Mexican amber, in Penney, D. (ed.), Biodiversity of fossils in amber from the major world deposits: Siri Scientific Press, 42-56.

Westfall, M.J., May, M.L., 1996, Damselflies of North America: Scientific Publishers, Inc., Gainesville, Florida, 649 p.

Manuscript received: November 27, 2014.

Corrected manuscript received: February 25, 2015.

Manuscript accepted: March 31, 2015. 